\title{
MITOLOGIZACJA I POLITYZACJA HISTORII: CO MOŻEMY WIEDZIEĆ, CO MOŻEMY ZROBIĆ I CZEGO MOŻEMY SIĘ SPODZIEWAĆ?
}

\section{Ewa SOLSKA}

Uniwersytet Marii Curie-Skłodowskiej

Powierzamy Czytelnikom zapis dyskusji wokół artykułu Jana Pomorskiego pt. Polityzacja/mitologizacja historii, czyli w czym neuronauka (i metodologia) może pomóc badaczowi historii najnowszej?' Pomysł na taką formę przekazu powstał w nawiązaniu do niedawnego spotkania w ramach Forum Badaczy Dziejów Najnowszych, zorganizowanego przez Polskie Towarzystwo Historyczne (Warszawa, 10 grudnia 2016 roku). Jego obrady pozostawiły wiele diagnoz, które postanowiliśmy w kilku wątkach uwydatnić i dopełnić. Jeżeli bowiem to, co zwie się mitologizacją i polityzacją historii ma znaczenie względem deontologii badań naukowych i edukacji historycznej, równie znaczącym tu odniesieniem będzie wynajdywanie nowych aspektów studiów nad pamięcią (i wyobraźnią kulturową), w tym tropów tego, co Jean-Pierre Dupuy nazywa „czasem projektu”, który przekłada się także na neuromarketingową formułę „projektowania doświadczenia”. Przy czym tematyka debaty sytuuje się w obecnym kontekście politycznym i społecznym w Polsce. Możemy dla przykładu brać jako symptom ubiegłoroczną warszawską edycję Festiwalu Filmowego WATCH DOCS, poświęconego problematyce praw człowieka, którą zdominował problem kształtowania pamięci zbiorowej w ramach polityki historycznej (patrz sekcja: „Rekonstrukcja. Polityka pamięci”). Wyzwaniem w pewnej mierze jest też niedawno wydana książka Jana Żaryna, pt. Polska

Wymogi formalne redakcji „Historii@Teorii” oraz warunki umowy wydawniczej sprawiły, że nie wszystkie wypowiedzi debaty udało nam się zamieścić. Profesor Pomorski odnosi się do nich w końcowej replice, dlatego przekazujemy adresy bibliograficzne artykułów, które Dyskutanci zasugerowali jako stosowną wykładnię ich koncepcji na tematy tutaj poruszane. Piotr Witek, Doktryna polityki historycznej - czyli dramat w kilku aktach, „Historyka. Studia metodologiczne” T. XLI, 2011; Marcin Zaremba, Wyziewy z fabryki mitów, „Polityka” nr 49 (3088), $30.11-6.12 .2016$. 
pamięć. O historii i polityce historycznej, którą możemy traktować jako wykładnię i apologię strategii (w tym obszarze) obecnej władzy w Polsce, wyrażanej pod hasłem „pedagogiki dumy narodowej” $i$ „końca pedagogiki wstydu”. Mamy więc punkt wyjścia, pytanie tylko - do czego? Odpowiedź zależy od strony sporu.

Nam wszakże nie chodzi o to, żeby kogoś przekonać czy przeprogramować na stuszne poglądy, ale o to - jak powiadał Wiktor Osiatyński - aby dać do myślenia. Profesor mawiał, że podstawą rozmowy, a zwłaszcza zadawania pytań, jest uważne słuchanie i czytanie. I my wierzymy, iż wyciągnie się wtedy, choćby z konwersacji w stylu: „Kąpał się pan w Malszy? Nie kąpałem, ale w tym roku może być dużo śliwek", nieoczekiwane i owocne wnioski. Aczkolwiek historykom i metodologom przypisuje się jeszcze jedną powinność: działać względem polityki historycznej jak dzisiejsi fact-checkers, których rolą, poza demaskowaniem manipulacji i fałszu w wypowiedziach polityków czy politykujących uczonych (i pseudonaukowców), jest także wynajdywanie kontekstów i objaśnianie sytuacji. Istotne jest tu usytuowanie względem zasady: „prawdziwi patrioci zadają pytania” (Carl Sagan), tym bardziej jeżeli ubi dubium ibi libertas.

Inicjujący niniejszą dyskusję tekst Jana Pomorskiego kieruje konsekwentnie w stronę zagadnienia: jak dzisiejsi politycy (czy szerzej - działacze przestrzeni publicznej) projektują dyskursy o przeszłości? Znana (choć niewyczerpująca) jest diagnoza: w Polsce bazując głównie na badaniach IPN oraz na społecznych efektach tzw. demokratyzacji dyskursu i masowej produkcji opracowań na tematy medialnie chłonne (które dobrze wpisują się w formaty teorio-spiskowe, tzw. wiedzę wernakularną oraz taktykę wywoływania konfliktów dla dzielenia społeczeństwa). Widzimy, że w obecnych dyskusjach nad przesłankami tych projektów dominuje w punkcie wyjścia i odniesienia historia polityczna, a relatywnie pomija się wątki historii kultury i historii idei; weźmy przykład koncepcji (nie tylko polskiego) mesjanizmu, a zwłaszcza ezoteryzmu (tu szczególnie wariant polski) w dwudziestoleciu międzywojennym. Z kolei stosunkowo nową perspektywą badań nad polityką historyczną i polityką pamięci może być neuromarketing. Mamy obecnie w metodologii nauk zwrot kognitywistyczny; postulat neuronauki w odniesieniu do metodologii historii jest znamiennym symptomem, choć J. Pomorski widzi tu także narzędzie dla historyka dziejów najnowszych, w roli badacza-demaskatora i tlumacza. W każdym razie nessun dorma; mierzenie czasu 
reakcji (np. na medialny wizerunek nielubianego polityka), jak kiedyś wyniki badań Pawłowa dla programowania propagandy, to narzędzie prawodawców, czyli tych, co projektują przyszłość (i poniekąd przeszłość). Jak rzekł był klasyk: „rząd musi pokazać, że rządzi, a wtedy szefowie mediów zaczną inaczej myśleć, a dziennikarze inaczej działać” - a potem zorganizuje się lud. Mierzenie czasu reakcji i neuromarketingowe sterowanie potrzebami klienckimi to w tym kontekście zaledwie krok od medialnego projektowania emocji, a kilka kroków od zarządzania pamięcią utajoną i w konsekwencji sterowania myśleniem. Oczywiście tego typu dystopijna transgresja przypomina raczej o możliwości kolejnej mrocznej prefiguracji „policji myśli” (której klasyczną wersję wspominamy od prawie 70 lat). Czy jednak obecna atmosfera (np. miesięcznic smoleńskich) w jakiejś mierze nie prowokuje do wysnuwania „czarnych” scenariuszy orwellowskich seansów mitości i nienawiści?

Neuromarketing i reklama ukierunkowana ilustrują mechanikę nowoczesnej propagandy, która ukazała się ostatnio w odsłonie mikrotargetowania psychograficznego (i, tradycyjnie, sprawnego wykorzystywania luk w prawie), jak naświetliły to niedawne śledztwa magazynów "The Observer” i „The Guardian” [patrz: The great British Brexit robbery: how our democracy was hijacked, by Carole Catwalladr, „The Guardian”, 7 may 2017]. Jednak mise-en-scène i główni aktorzy pozostają jak byli - kto tworzy dziś kantowską historię a priori? Niezmiennie politycy i media, choć apologeci metody prof. Michała Kosińskiego i działań Cambridge Analytica mają tu nieodzowną skłonność do automitologizacji. Tym bardziej warto iść tropem zmarlego niedawno Boba Silversa, redaktora „The New York Review of Books” i wziąć (raczej niż wziąść) jego dictum: „Musimy odkryć nową formę krytyki (...). Jeśli zależy nam na rozumnym korzystaniu z języka i związanych z tym wartościach (...) musimy poddać ten potężny ocean słów krytyce” [za: J. Zgierski Zredagować chaos, „Dwutygodnik”, 04/2017]. Zatem metadane i AI oraz niezmiennie rygor warsztatu naukowego, refleksja metodologiczna ... i nieufność wobec władzy. To jednak temat na kolejną opowieść.

Tymczasem mamy pytanie: jakiej polityki historycznej (i polityki pamięci) potrzebuje dzisiaj Polska (i Europa) oraz - za Jerzym Jedlickim - jakiego patriotyzmu Polacy potrzebują (i jakiego patriotyzmu potrzebują Europejczycy)? Tutaj sytuujemy się względem dyskursu mitologicznego (i nowych rewizjonizmów). 
Mitologia jest przestrzenią metafory, symbolu i przypowieści; jest jedną z „gramatyk tworzenia" (Georg Steiner) i najskuteczniejszym chyba dyskursem legitymizacji władzy. Ale w pamięci kulturowej Europy jest jeszcze jednym, być może najbardziej otwartym, z „systemów wyjaśniania przyczynowości” (Josif Brodski w przedmowie do Zaślubin Kadmosa z Harmonia Roberto Calasso). Z jednej strony mamy więc dalekie echa postulatu „mocnej myśli” (Maurizio Ferraris) w odpowiedzi na porażki kolejnych projektów emancypacyjnych i w perspektywie kolejny akt mitoburstwa-mitotwórstwa (np. mit monokulturowego narodu i jego elit dobrej zmiany - w stronę suwerennego państwa narodowego oraz scentralizowanej władzy jako gwaranta narodowej ciągłości - przeciwko korporacyjnemu układowi neoliberalnego, kosmopolitycznego estabilishmentu). Z drugiej strony mamy politykę postprawdy, manipulacji semantycznej lub nieudowodnionej hipotezy, której przeczy wszystko, co jest naukowo argumentowane, ale wspiera teoria spiskowa, taktyka insynuacji i poczucie misji do spełnienia, przeciwstawione poczuciu wątpliwości (opartym na zobowiązaniu wobec zasady prawdziwego świadectwa) i metodycznemu sceptycyzmowi. Powstaje w efekcie dyskurs w kolejnym obszarze dzielący społeczeństwo, a fundujące wspólnotę metafory stają się „kategoriami zombi” (Urlich Beck). W państwie półperyferyjnym przekłada się to na rozległe marnotrawstwo społecznego, kulturowego i obywatelskiego kapitału, co trudno będzie zrekompensować i naprawić w perspektywie niedługiego trwania. Dlaczego tak się dzieje? Niniejsze teksty poszukują i na to odpowiedzi; jednym z tropów będzie tu również presumpcja wynalezionej na nowo drogi do „tyranii” w aktualnym wydaniu populistycznego nacjonalizmu (patrz: Timothy Snyder, O tyranii. Dwadzieścia lekcji z dwudziestego wieku).

Wiodącą wobec tego kwestią wydaje się być to, na ile racjonalnie odbieramy komunikaty od polityków i przeciwników ideologicznych, a przy tym - czy dostatecznie wykorzystujemy współczesne narzędzia analizy oraz metody krytyki (dyskursu). Pamiętamy też, że obecna ekipa rządząca w Polsce przyszła pod szyldem zmiany rzeczywistości politycznej i sanacji moralnej. Wprawdzie metodą „amoralnego familizmu” (Edward C. Banfield) selekcjonując „naszych” i „tamtych=wrogów/zdrajców" na wstępie, ale czego się nie robi dla rewolucji, zwłaszcza w kombinacie polityki historycznej i polityki pamięci. Podobno i historia non facit saltus, tym bardziej więc w dzisiejszej atmosferze trzeba być czujnym wzglę- 
dem tego, czy zmierzamy w stronę projektu wspólnoty aksjologicznej i socjalnej emancypacji grup wykluczonych, czy w stronę Oceanii z Roku 1984. Jej ustrój zwany angsocem fundują zasady „nowomowy”, „dwójmyślenia” i „zmienności przeszłości", ustanowione w świetle pragmatycznej prawdy systemu, wyrażonej sloganem Partii: „Kto rządzi przeszłością, ten ma w rękach przyszłość; kto rządzi teraźniejszością ten ma w rękach przeszłość”. To tak dla przypomnienia.

Zapraszamy do lektury i dyskusji 